\title{
A Brief Report for Trading Game
}

Yibin Liu

\begin{abstract}
This paper summarizes trade details, strategy made, and the participant learned through trading on STOCKTRAK game. The Yibin Liu report also includes the profits and losses, every trade made on derivatives products, the timing for buying and selling and gain some practical experience.
\end{abstract}

How to cite this article:

Keywords: trading strategies and motivations, empirical edificaYibin Liu. A Brief Report for Trading tion Game. Global journal of Economics and Business Administration, 2018, 3: 9.

\section{eScîPub}

eSciPub LLC, Houston, TX USA.

Website: http://escipub.com/ 


\section{Profile}

Benchmark interest rate has been lifted from $0.25 \%$ to $0.5 \%$ by Bank of England since 2007 . Market response quickly and some investors already obtained profits.

The news proves again that the changes of investment market is complicated, and volatility of derivatives is difficult to predict in the dynamitic market. Therefore, the practical experiment is necessary for us. We tried to trade with various derivatives as much as possible, including stocks / ETFs, options, mutual funds, futures, future options, bounds and spots on STOCKTRAK game. The market changing was reflected through profits and losses shift on investors' virtual account with

$€ 1000,000$ initial funds. This experiment assisted us with knowing investment market directly and using knowledge in an empirical method.

\section{Overall profits \& losses}

I totally ordered thirteen trades with equities, a stock option and a future[ The future was expired, this trade will be illustrated in "empirical edification "part.] in the past four weeks. Figure 1 summarizes the basic information on virtual account. Total returns take 1.22 percentage of $€ 1,002,204.40$ balance, thirteen trades worth $€ 4,170.89$ positions on net market value. And commissions totally cost $€ 23.78$ (currency exchange rate: $€ 1=\$ 1.18$ ).

\subsection{Profits}

The most profitable derivatives are equities in portfolio. Figure 2 describes the greatest part of return is from equity 603499 by 1500 positions with $€ 6,281.49$.

Figure 1. Basic information of portfolio

\begin{tabular}{|c|c|}
\hline Market Value & \\
\hline Market Value of Long Positions & $€ 4,170.89$ \\
\hline Net Market Value of all Positions & $€ 4,170.89$ \\
\hline Portfolio Summary & \\
\hline Portfolio Value & $€ 1,002,204.40$ \\
\hline Percentage Return & $0.22 \%$ \\
\hline Buying Power & $€ 998,033.51$ \\
\hline Trades Made/Allowed & $13 / 9987$ \\
\hline Current SPY ETF & $€ 258.09$ \\
\hline SPY ETF at start date & $€ 254.95$ \\
\hline SPY ETF \% Return & $1.22 \%$ \\
\hline
\end{tabular}

Figure 2. Details of profitable Derivatives

\begin{tabular}{|c|c|c|c|c|c|c|}
\hline Transaction Type & Security & Symbol & Company Name & QTY & Price (¥) & Amount $(€)$ \\
\hline Market - Sell & EQUITIES & 603683 & $\begin{array}{c}\text { Shanghai Smith Adhesive } \\
\text { New Material Co., Ltd. }\end{array}$ & -25 & 17.91 & 57.09 \\
\hline Stop - Sell & EQUITIES & 603922 & $\begin{array}{c}\text { Suzhou Jin Hong Shun } \\
\text { Auto Parts Co., Ltd. }\end{array}$ & -500 & 37.25 & $2,409.49$ \\
\hline Stop - Sell & EQUITIES & 603499 & $\begin{array}{c}\text { Shanghai Sunglow } \\
\text { Packaging Technology Co., } \\
\text { Ltd. }\end{array}$ & -1500 & 32.37 & $6,281.49$ \\
\hline Stop - Sell & EQUITIES & 603683 & $\begin{array}{c}\text { Shanghai Smith Adhesive } \\
\text { New Material Co., Ltd. }\end{array}$ & -1005 & 29.11 & $3,807.70$ \\
\hline
\end{tabular}


Figure 3 indicates that equity 603499 , equity returns with $50 \%, 31 \%$ and $19 \%$ of the 603683 and equity 603922 respectively earn proportion on total returns.

\section{Figure 3. Proportion of return from different equities}

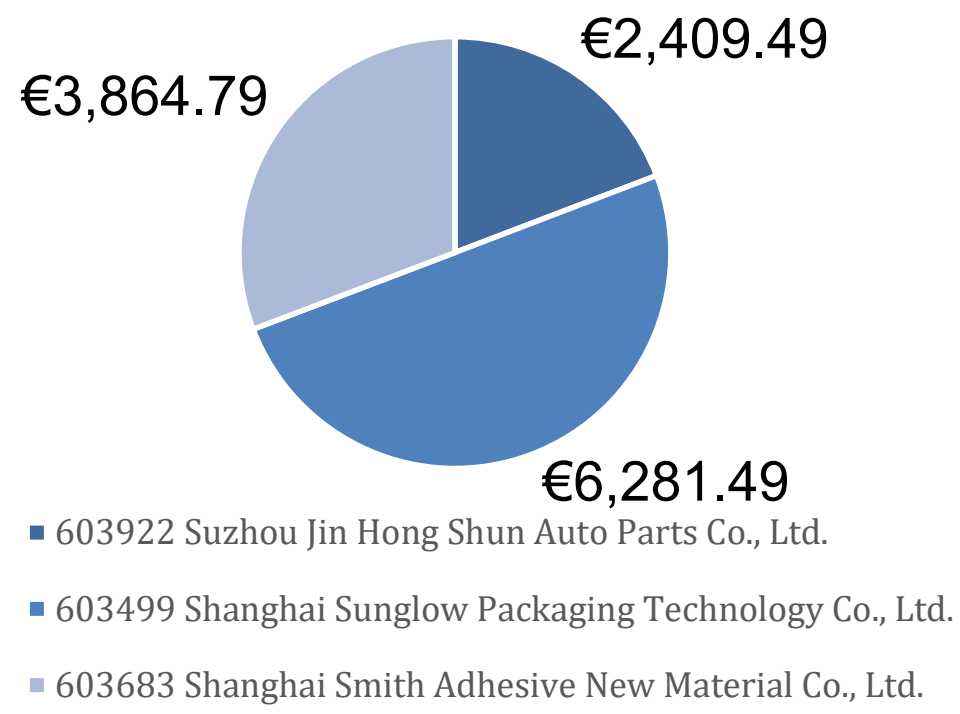

\subsection{Losses}

Figure 4. Details of Losing Derivatives

\begin{tabular}{|c|c|c|c|c|c|c|c|}
\hline Trade Date & Transaction Type & Security & Symbol & Company Name & QTY & Price (¥) & Amount( $€)$ \\
\hline $10 / 23 / 2017$ & Market - Buy & EQUITIES & 603103 & $\begin{array}{c}\text { Hengdian Entertainment } \\
\text { Co., Ltd. }\end{array}$ & 15 & $¥ 43.36$ & $€-83.38$ \\
\hline $10 / 25 / 2017$ & Market - Sell & EQUITIES & 603103 & $\begin{array}{c}\text { Hengdian Entertainment } \\
\text { Co., Ltd. }\end{array}$ & -15 & $¥ 43.50$ & $€ 83.19$ \\
\hline $10 / 23 / 2017$ & Limit - Buy & EQUITIES & 600490 & Shanghai Synica Co Ltd & 20 & $¥ 10.93$ & $€-28.02$ \\
\hline $10 / 23 / 2017$ & Limit - Buy & EQUITIES & 603717 & $\begin{array}{c}\text { Tianyu Ecology \& } \\
\text { Landscape Co Ltd }\end{array}$ & 30 & $¥ 32.25$ & $€-124.03$ \\
\hline $11 / 10 / 2017$ & Limit - Buy & OPTIONS & $\begin{array}{c}\text { BABA1717 } \\
\text { K } \\
177.5\end{array}$ & $\begin{array}{c}\text { Alibaba Grp Shs } \\
\text { Sponsored American } \\
\text { Deposit Share R }\end{array}$ & 5 & $\$ 10.00$ & $€-4,294.39$ \\
\hline
\end{tabular}

\section{Trade}

Obviously, the price of the derivatives remained with a stable tendency in the portfolio.And the cheapest derivative is a Chinese stock approximately by $€ 1$ (equal to $¥ 10.93$ in Figure $5)$ per share. The most profitable derivative has the biggest quantity of positions.

The pie chart (Figure 6) describes thirteen transactions, including 3100 positions that mostly divide by stock 603499 (with 1500 positions), stock 603683(with 1030 positions)
The pie chart (Figure 6) describes thirteen transactions, including 3100 positions that mostly divide by stock 603499 (with 1500 positions), stock 603683(with 1030 positions) and stock 603922 (with 500 positions), whereas other stocks and an option only take small proportion on total volume.

\section{Trading strategies and motivations}

and stock 603922 (with 500 positions), whereas other stocks and an option only take small proportion on total volume. 
Yibin Liu, GJEBA, 2018; 3:9

Figure 5. Transaction details

\begin{tabular}{|c|c|c|c|c|c|c|c|}
\hline Trade Date & $\begin{array}{l}\text { Transacti } \\
\text { on Type }\end{array}$ & Security & Symbol & Company Name & QTY & Price $(¥)$ & Amount $(€)$ \\
\hline $11 / 10 / 2017$ & $\begin{array}{l}\text { Limit - } \\
\text { Buy }\end{array}$ & OPTIONS & $\begin{array}{c}\text { BABA171 } \\
7 \mathrm{~K} 177.5\end{array}$ & $\begin{array}{l}\text { Alibaba Grp Shs Sponsored } \\
\text { American Deposit Share R }\end{array}$ & 5 & 63.00 & $-4,294.39$ \\
\hline $11 / 9 / 2017$ & $\begin{array}{l}\text { Stop - } \\
\text { Sell }\end{array}$ & $\begin{array}{l}\text { EQUITIE } \\
\qquad S\end{array}$ & 603922 & $\begin{array}{c}\text { Suzhou Jin Hong Shun Auto } \\
\text { Parts Co., Ltd. }\end{array}$ & -500 & 37.25 & $2,409.49$ \\
\hline $11 / 9 / 2017$ & $\begin{array}{l}\text { Stop - } \\
\text { Sell }\end{array}$ & $\begin{array}{l}\text { EQUITIE } \\
\qquad S\end{array}$ & 603499 & $\begin{array}{c}\text { Shanghai Sunglow } \\
\text { Packaging Technology Co., } \\
\text { Ltd. }\end{array}$ & -1500 & 32.37 & $6,281.49$ \\
\hline $11 / 8 / 2017$ & $\begin{array}{l}\text { Stop - } \\
\text { Sell }\end{array}$ & $\begin{array}{l}\text { EQUITIE } \\
\qquad S\end{array}$ & 603683 & $\begin{array}{l}\text { Shanghai Smith Adhesive } \\
\text { New Material Co., Ltd. }\end{array}$ & -1005 & 29.11 & $3,807.70$ \\
\hline $11 / 7 / 2017$ & $\begin{array}{l}\text { Limit - } \\
\text { Buy }\end{array}$ & $\begin{array}{l}\text { EQUITIE } \\
S\end{array}$ & 603922 & $\begin{array}{c}\text { Suzhou Jin Hong Shun Auto } \\
\text { Parts Co., Ltd. }\end{array}$ & 500 & 36.09 & $-2,345.21$ \\
\hline $11 / 7 / 2017$ & $\begin{array}{l}\text { Limit - } \\
\text { Buy }\end{array}$ & $\begin{array}{l}\text { EQUITIE } \\
\text { S }\end{array}$ & 603499 & $\begin{array}{c}\text { Shanghai Sunglow } \\
\text { Packaging Technology Co., } \\
\text { Ltd. }\end{array}$ & 1500 & 31.89 & $-6,216.84$ \\
\hline $11 / 7 / 2017$ & $\begin{array}{l}\text { Market - } \\
\text { Buy }\end{array}$ & $\begin{array}{l}\text { EQUITIE } \\
\quad S\end{array}$ & 603683 & $\begin{array}{l}\text { Shanghai Smith Adhesive } \\
\text { New Material Co., Ltd. }\end{array}$ & 1000 & 27.92 & $-3,628.60$ \\
\hline $10 / 25 / 2017$ & $\begin{array}{l}\text { Market - } \\
\text { Sell }\end{array}$ & $\begin{array}{l}\text { EQUITIE } \\
S\end{array}$ & 603103 & $\begin{array}{l}\text { Hengdian Entertainment Co., } \\
\text { Ltd. }\end{array}$ & -15 & 43.50 & 83.19 \\
\hline $10 / 25 / 2017$ & $\begin{array}{l}\text { Market - } \\
\text { Sell }\end{array}$ & $\begin{array}{l}\text { EQUITIE } \\
S\end{array}$ & 603683 & $\begin{array}{l}\text { Shanghai Smith Adhesive } \\
\text { New Material Co., Ltd. }\end{array}$ & -25 & 17.91 & 57.09 \\
\hline $10 / 23 / 2017$ & $\begin{array}{l}\text { Market - } \\
\text { Buy }\end{array}$ & $\begin{array}{l}\text { EQUITIE } \\
\quad S\end{array}$ & 603103 & $\begin{array}{l}\text { Hengdian Entertainment Co., } \\
\text { Ltd. }\end{array}$ & 15 & 43.36 & -83.38 \\
\hline $10 / 23 / 2017$ & $\begin{array}{l}\text { Limit - } \\
\text { Buy }\end{array}$ & $\begin{array}{l}\text { EQUITIE } \\
S\end{array}$ & 600490 & Shanghai Synica Co Ltd & 20 & 10.93 & -28.02 \\
\hline $10 / 23 / 2017$ & $\begin{array}{l}\text { Limit - } \\
\text { Buy }\end{array}$ & $\begin{array}{l}\text { EQUITIE } \\
S\end{array}$ & 603683 & $\begin{array}{l}\text { Shanghai Smith Adhesive } \\
\text { New Material Co., Ltd. }\end{array}$ & 30 & 14.80 & -56.92 \\
\hline $10 / 23 / 2017$ & $\begin{array}{l}\text { Limit - } \\
\text { Buy }\end{array}$ & $\begin{array}{l}\text { EQUITIE } \\
\text { S }\end{array}$ & 603717 & $\begin{array}{l}\text { Tianyu Ecology \& Landscape } \\
\text { Co Ltd }\end{array}$ & 30 & 32.25 & -124.03 \\
\hline
\end{tabular}

Source: http://www.stocktrak.com

Figure 6. proportion of quantity from different Derivatives

\footnotetext{
- Hengdian

Entertainment Co., Ltd.

- Shanghai Synica Co Ltd

- Tianyu Ecology \&

Landscape Co Ltd

- Alibaba Grp Shs

Sponsored American

Deposit Share R

- Suzhou Jin Hong Shun

Auto Parts Co., Ltd.
}

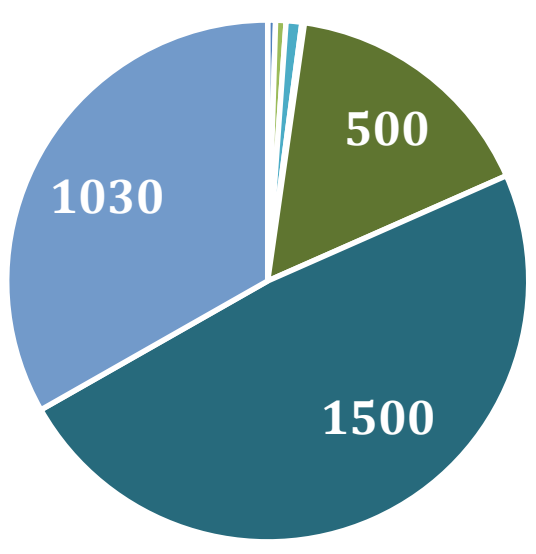




\subsection{To set a goal}

Based on limited trading days and $€ 1000,000$ initial balance on virtual account, to gain profits and to mitigate risks as more as possible are primary target. Firstly, I am a risk averter and

\subsection{To choose investment market}

The Chinese investment market was driven by government policy upon most occasions. During trading days, a very important party meeting was convened. Government usually proposed new policies and guidelines at this conference and financial market would response these documents within two days maximumly. Equities price of some companies particularly increased if their industry was indicated to government documents in the meeting. The government emphasized the green development this year and refer to environmental governance. Thus, certain industries would have government supports in the future, such as the industry about new energy, new materials, and landscaping.

In addition, the trading period near to "Double 11 shopping carnival”, this online shopping prefer to choose one investment with lower risk than another one, even they both have same expected rate of return. Secondly, I plan to arbitrage through a series of transactions that can offset with each other.

carnival was holding by Alibaba Group, the biggest Chinese e-commerce conglomerate. They earned $¥ 120.7$ billion revenue on 11 th November 2016. Since they had IPO in NYSE on 19 September 2014, their share would be ups and down around November.

\subsection{To screen out equities}

Firstly, I selected some stocks by their performances on website of Shanghai Stock Exchange in trading days. Secondly, I screened stocks out via turnover rate. A turnover rate implies the investors' confidence about this stock. If a stock had high turnover rate, it may have high level of liquidity and low level of confidence from investors. Due to the negative expectation, investors want to trade a highturnover rate stock as soon as possible.

The selected stocks as Figure 7 shows:

Figure 7. the selected stock

\begin{tabular}{|c|c|c|}
\hline & Symbol & Company Name \\
\hline 1 & 603922 & Suzhou Jin Hong Shun Auto Parts Co., Ltd. \\
\hline 2 & 603499 & Shanghai Sunglow Packaging Technology Co., Ltd. \\
\hline 3 & 603683 & Shanghai Smith Adhesive New Material Co., Ltd. \\
\hline 4 & 603103 & Hengdian Entertainment Co., Ltd. \\
\hline 5 & 600490 & Shanghai Synica Co Ltd \\
\hline 6 & 603717 & Tianyu Ecology \& Landscape Co Ltd \\
\hline
\end{tabular}

Source:http://www.stocktrak.com

Taking equity 603683 (company Shanghai Smith Adhesive New Material Co., Ltd.) as an example: Their products were made from new materials, for instance, rice and was sold nationally. This company had $¥ 3,159.1$ million on market capital, $¥ 833.51$ million on total assets, and earned $¥ 166.83$ million quarterly revenue in the first quarter of 2017 .

According to the basic information above, this company already found a right position in GJEBA: http://escipub.com/global-journal-of-economics-and-business-administration/ 0005 
market and had their unique advantage. Most attractive is that their products and idea had same direction with government new policy, it demonstrated that company's manager was good at planning for big picture, this company might have big chance to expand and would have good performance on stock market in the trading period.

\subsection{To wait a suitable time}

Firstly, to collect historical price for every stock. I believe that history has a continuous cycle, there is no exception as well as on stock market. The past price of equity 603683 (Figure8)

\section{Figure 8. Historical Price for Equity 603683}

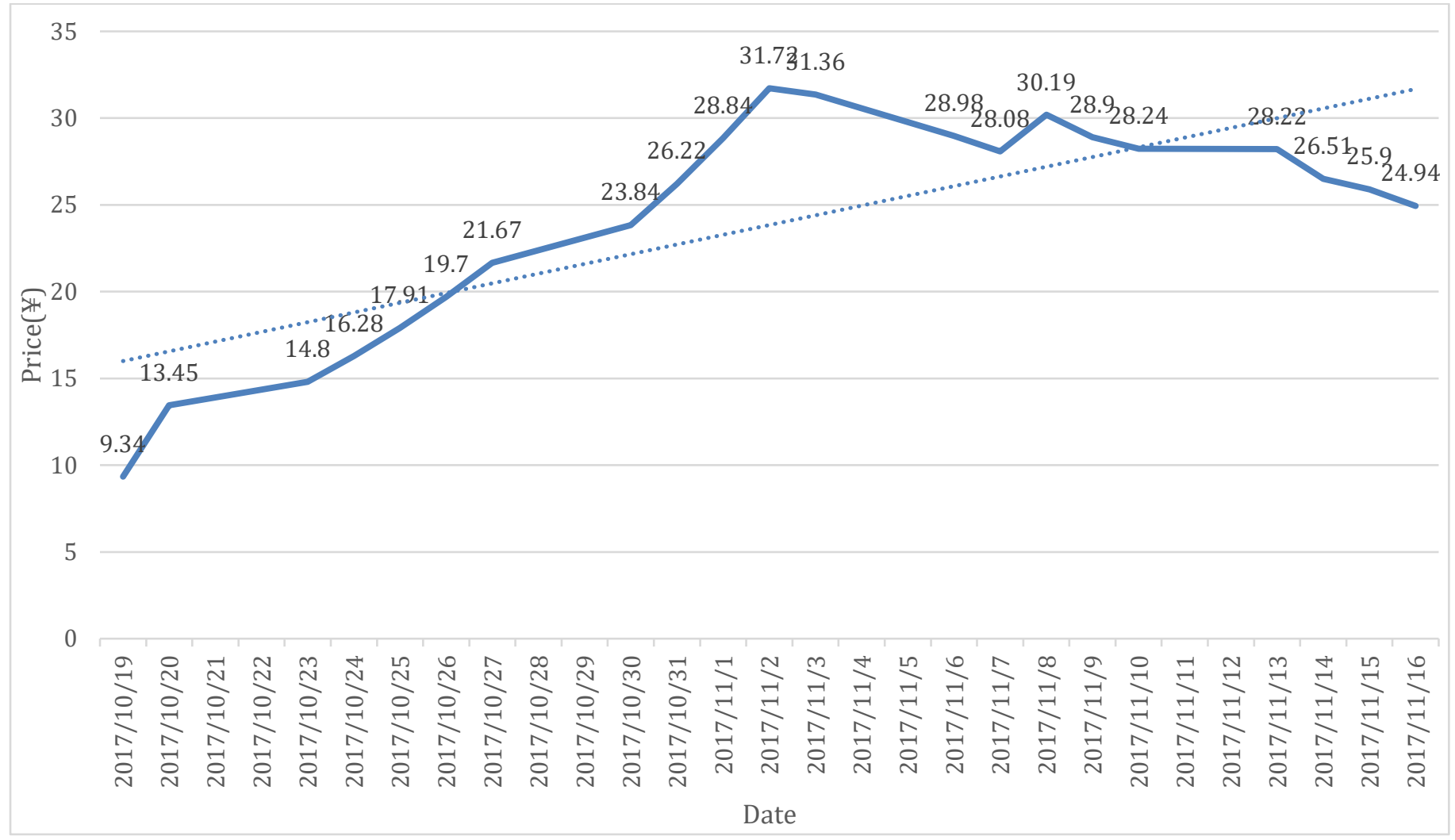

Figure 9. Historical volume for Equity 603683

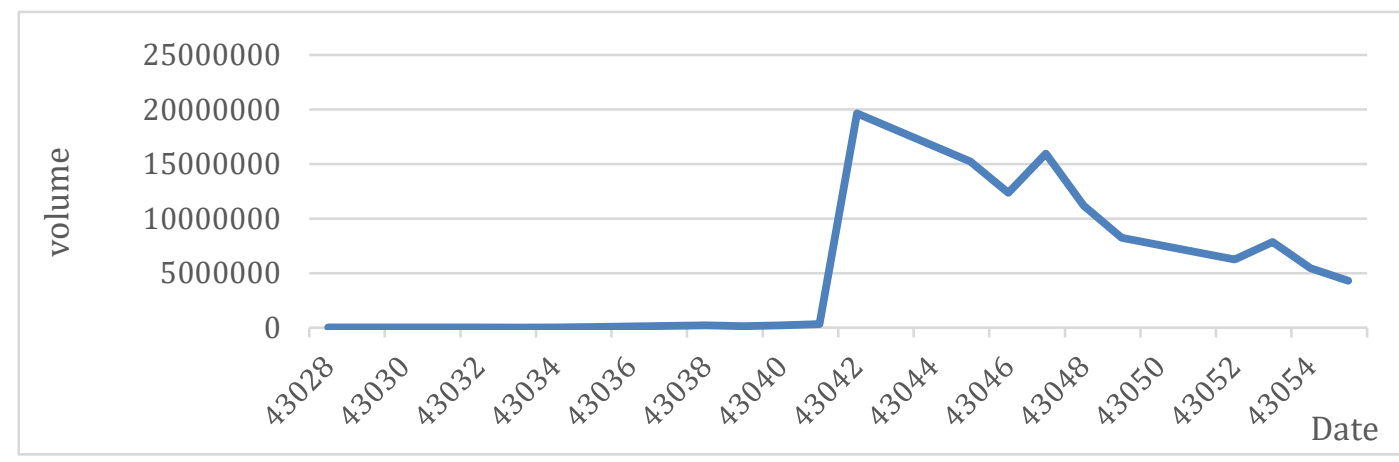

Secondly, three data signified a great time to buy equity 603683 on 23th October 2017. The $0.01 \%$ of turnover rate was markedly low, the stock price didn't reach historical peak time
(Figure 8), and volume was relatively low as well (Figure 9). The low turnover rate and volume of transaction indicated that most investors still highly expected this equity could 
performance better at end of October or even at beginning of November.

Thus, I continuously bought this stock with 30 positions and 1000 positions on the game.

\subsection{A time difference}

Owing to 8-hours difference between Ireland and China, I select limit or stop price to transact. No immediately response on market changing was a major problem that occurred by time lag. These transaction type partly resolve the problem and mitigate risks.

\section{Empirical edification}

We approached typical derivatives products that highly related to our basic knowledge for derivatives on STOCKTRAK game. The fluctuation in market also impacted on our virtual account with balance dramatically changed. Based on the four-weeks trading I mainly learned three piratical experiences.

\subsection{Finding an appropriate market}

This game let me understand that profits highly correlate with risks, if I want to obtain more returns within one month, even I am averse to risk, I should choose a market with more volatility than Chinese investment market. This enlightened me that a great investing environment is not a stable market, is a market that meet investors' demands, maybe it's a fluctuant market or a market has tendency which is driven by private information.

\subsection{Commission costs}

Since I didn't earn a lot of money by implementing the cautious strategy, then every cent counts. But one trade costed $\$ 10$ or $¥ 10$, the commission totally costed $\$ 28$ (currency exchange rate: $\$ 1=¥ 6.63$ ) in trading period. I didn't think highly of the commission costs, and frequently traded with small amount every time. And if I got more losses on portfolio, the commission will hold a considerable part of amount of total loss.

\subsection{Impact from market fluctuations}

To avoid some risks that from market volatility I invested very careful. At meanwhile, I lost profits. When Nasdaq index dramatically moved between 26th October and 4th November (Figure 10), my strategies prevent loss happened and contribute profits to other investors in the same period. This sacrifice on profits is specifically describe on Figure 11 and Figure 12: When S\&P 500 and Dow Jones index greatly increased after 31th October, percentage return only rose $0.05 \% \quad(=0.24 \%$ $0.19 \%)$.

Figure10. Nasdaq ETF (\%) VS. portfolio Return (\%)
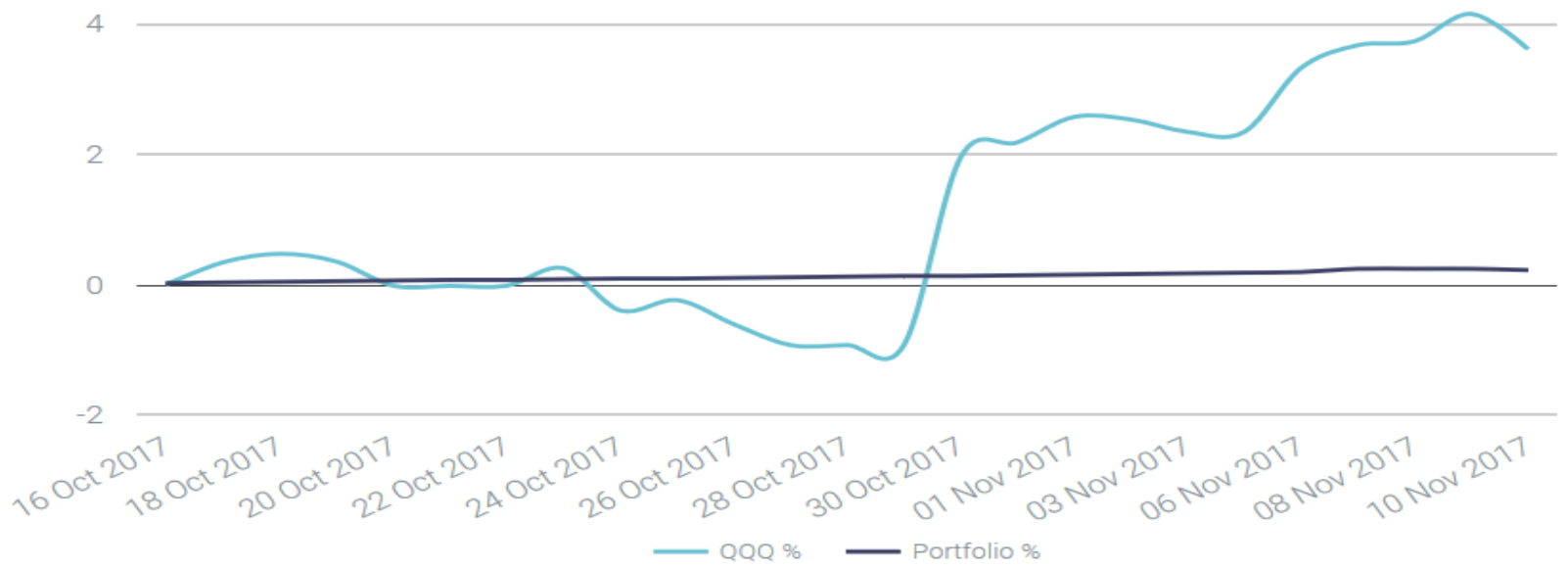


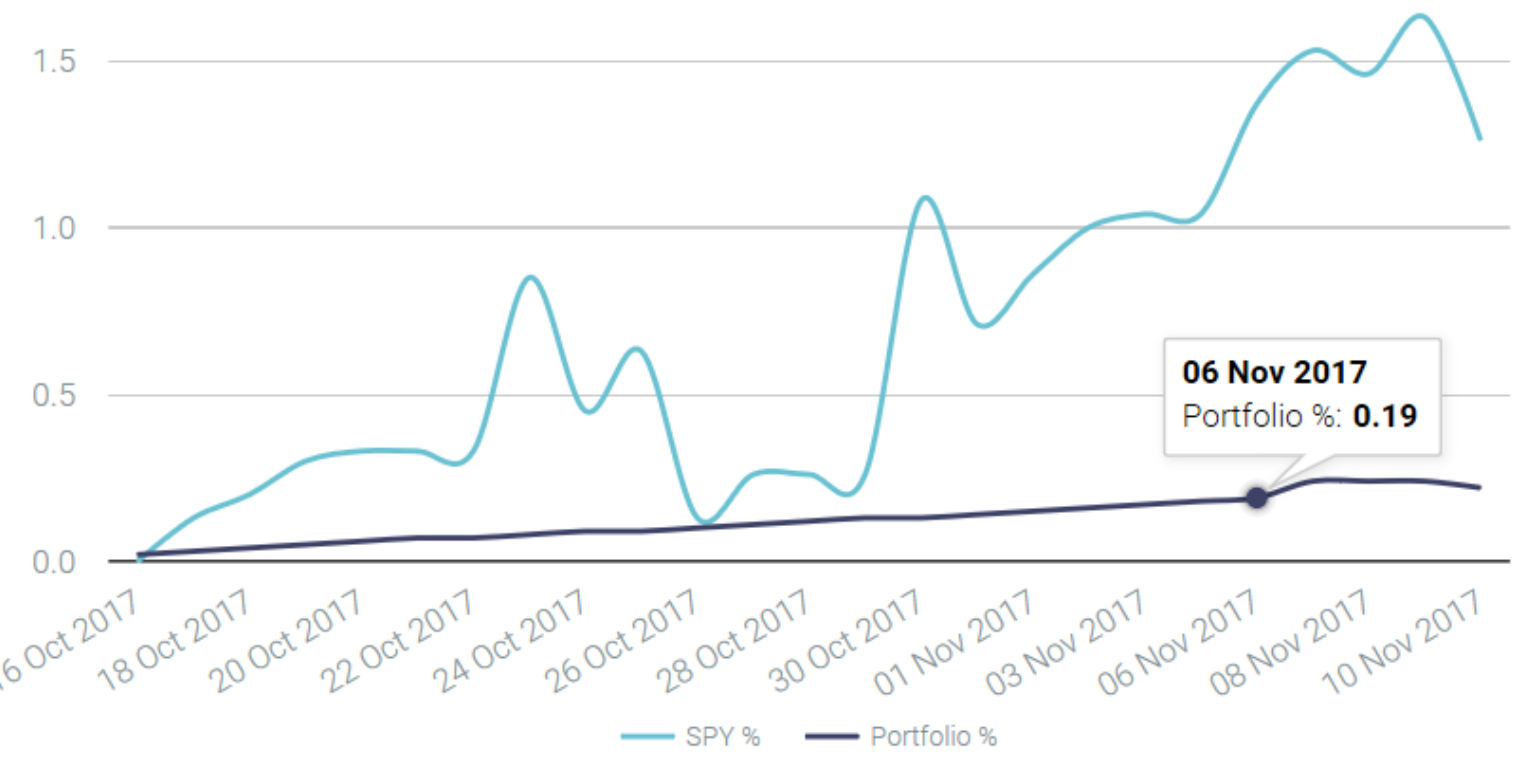

Source: http://www.stocktrak.com

Figure 12. Dow Jones ETF (\%) VS. portfolio Return (\%)

Portfolio Overview

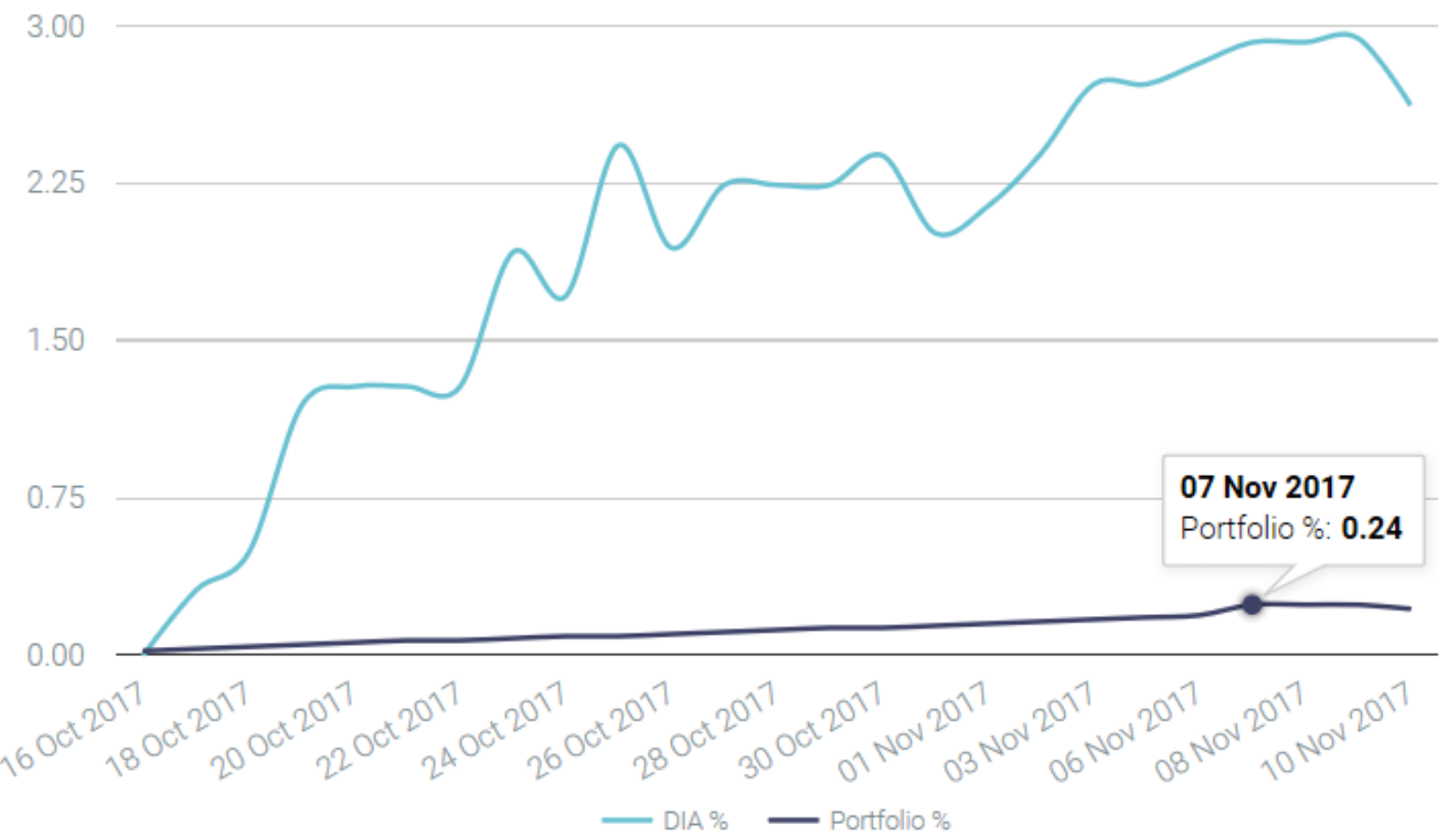

Apparently, it's not difficult to observe and market change. Besides, the expired future predict the market trend like this, two major reminds me stick to the date of delivery. Missed index both ascend in the same time. I need to the delivery time makes me lose a chance to practice more to acquire keen sense of the deal with futures. 
Yibin Liu, GJEBA, 2018; 3:9

This game let me experience the dynamic more attractive because changes of derivatives market by means of trading basic and practical highly interact with variable market.

derivatives. Furthermore, derivatives products

\section{References}

1 John C, H. (2015). The Options, Futures, and Other Derivatives (9th ed.) Toronto: Pearson Education.

2 URL: http://www.stocktrak.com/

3 URL : http://www.bbc.com/news/business41846330

4 URL: http://www.sse.com.cn/

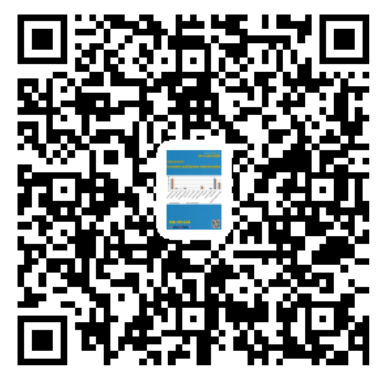

